\title{
Social resilience - local responses to changes in social and natural environments
}

Harald Beyer Broch

Correspondence:

h.b.broch@sai.uio.no

Department of Social Anthropology,

University of Oslo, Oslo, Norway

\section{Abstract}

Based on extensive empirical ethnographic fieldwork in northern Norway, the article examines social or cultural resilience and life quality in an island, fishing-based community. It is argued that resilience and life quality are interconnected when social or cultural resilience is considered. Life quality, not synonymous with life style or living standard, provides motivation (or lack of it) to cope or be resilient in times of social and environmental uncertainty and change. It is argued that community adaptation should be understood as resilient, but not just because contemporary residents are living at the same location as their forefathers. In spite of marked changes in resources utilized through generations, fish and fishing have continuously been, and still are regarded as, crucial to community viability and self ascribed identity of the residents.

Keywords: Coastal fisheries; Social resilience; Adaptation; Life quality; North Norway; Ethnography

\section{Social resilience? local responses to changes in social and natural environments}

The concept 'social resilience' and the emic - or fishermen's - perception of 'life quality' are central in this exposition. It is argued that the two are linked when the fishermen at Helligvær, Norway consider the possibilities for their current and future marine adaptation. Resilience is a vague concept, at times left undefined (Olwig 2009) and it appears in a variety of research disciplines (Sherrieb and Norris 2009). Resilience has also been applied to analyze the capacity of systems at different levels, such as animal populations, human individuals, households, communities, regions or nations to cope, manage or adjust to environmental changing conditions (Tuler et al. 2008).

Collectivities do not make decisions, rather, it is persons who do. In this article the concept of 'social resilience' is indicated by the ability of a significant number of local dwellers to respond viably to surprising or unpredicted changes in natural and social environments. According to Hastrup (2009:20) resilience in socio-ecological systems resides inside people. Furthermore, few natural and/or social systems are completely isolated or closed, and most are in flux. This flux arises from a dynamic person-system relationship of mutual interdependence. Cultural and personal values are thus highly significant in studies of social resilience. Resilient behavior requires 'extended flexibility' (Hastrup 2009b: 265-267) - a flexibility that extends through a variety of different social settings and cultural contexts. Whether adjustments to novel conditions and

(c) 2013 Broch; licensee Springer. This is an Open Access article distributed under the terms of the Creative Commons Attribution License (http://creativecommons.org/licenses/by/2.0), which permits unrestricted use, distribution, and reproduction in any medium, provided the original work is properly cited. 
circumstances take place within the family, local community arrangements, or commercial fishing - social resilience achieved through needed creativity is ultimately "an aspect of agency - and thoroughly social" (Hastrup 2009a:28). Social resilience is an outcome of applied knowledge regimes concerning technology, national and international markets, national politics - funneled through the personality of the fishermen, their household members and significant others in the community. This implies, I shall argue, that particular persons' positive and negative perceptual emotional experiences of commercial fishing, as well as fishing related community feedback, are crucial mechanisms of social resilience.

'Life quality' is a phrase frequently used by fishermen when they explain their attachment to the sea and to fishing activities. However, "[a]ttempts to generalize about a group of people as diverse as fishermen are destined to be confronted with cases which run counter to generalizations" (Pollnac 1988:23). There are two or three fishermen in this study who disagree with the majority about the kind of living commercial fishing entails. Their narrative explanations about why they ended up as commercial fishermen are different from the rest when they argue that they fish because they see no other alternative. They know no other trade and say that the quality of their lived lives is poor. A fisherman's life is nothing but hard work, often hampered by stormy weather onboard the bouncing workspace on a small vessel that offers less than satisfactory comfort, often far away from one's home, children and wife. Not surprisingly, successful fishermen usually tell different stories. Generally they express satisfaction, joy and commitment to their marine occupation. They say fishing is a cherished way of life.

The expression life quality may appear similar and related to the concepts 'standard of living' and 'life style'. Standard of living is primarily defined and measured by income and available material goods and necessities. Life style can be defined as "an integrated set of habits and practices which both meet consumption needs and provide the basis for constructing social identities" (Smith and Goldblatt 2000:64). In other words: Both analyses of 'standard of living' and 'life style' usually conceptualize persons' lives as economically and structurally determined. Thus both of these concepts are applied by sociologists and politicians to estimate manifestations of structural characteristics. 'Life quality', on the other hand, takes not only the material and structural dimensions into account. 'Life quality' as an analytical concept redirects focus from the structural to intangible cultural values experienced by persons. Considering life quality means taking into account concrete persons' expressed and experienced evaluations of their own lives.

A high or positive life quality expressed by fishermen may be interpreted as being equivalent primarily to positive work and community experiences (Vittersø 1991). However, life quality as the outcome of fishing activities is marked by different opinions among Helligvær fishermen. It would be a mistake to presume that all people who enact similar behaviors, like commercial fishing, share the same experience of, or motives for, those enactments (Hollan 2012). To come to grips with individual differences of motivation, a person-centered ethnographic approach (Hollan 2001) is applied in the following analysis. Everyone can be told how fishing should be carried out, but to internalize the "right feelings" or commitment to the profession is another matter. One can be taught that some form of behavior should be joyful and a particular identity rewarding but yet experience them as unimaginably poignant or tragic. Highlighting life quality, as expressed by the fishermen and by analysis of cultural insights, is an attempt 
to indicate how aspects of personal and emotional experience are shaped by both idiomatic and idiosyncratic factors (Hollan 2012). These personal experiences are in turn fundamental to social resilience because they serve to strengthen motivation for relevant actions of adaptation.

After a short ethnographic overview three sections follow: The first focuses on the islanders' resource utilization and the significance of flexibility as a possible foundation for resilience. The second section presents fishermen's values, identity, work, reputation and position within the community. The third section demonstrates how various natural resources and personal and cultural values and perceptions are interrelated and important when assessing social resilience.

\section{The ethnographic setting}

The ethnographic material on which this analysis rests was gathered during participant observation primarily onboard four of 26 locally owned fishing vessels. Fieldwork was carried out in the local community of Helligvær, during fishing activities in local waters and fishing off the coast of the Røst islands, Lofoten, and on the banks off the coast of Troms County. The fishing vessels are of the sjark design, with the wheelhouse towards the prow, and are between 11 and 15 meters long. They were rigged for fishing with halibut lines (gangvad), long lines, gill nets, ocean pots and jigging machines. Most vessels were prepared for two or more types of gear. I was based in Helligvær for a year during 2006-2007. In all, my fieldwork amounted to 15 months.

Helligvær is a fishing-based island community (Clay and Olson 2007) situated by Vestfjorden, in Nordland County, Norway. It takes one hour by hurtigbåt (high-speed catamaran passenger carrier) to reach Helligvær from Bodø, the district's capital. The community is located on six of the largest of the 365 tiny islands and islets that together constitute Helligvær. This is one of the outmost settlements fringing the North Atlantic Ocean. The largest island, Vokkøy, also boasts the highest peak, at 50 meters above sea level. The total population numbers approximately one hundred permanent residents. During the summer months, the population almost doubles when vacationers move into their holiday homes and even more of the islands are inhabited.

Helligvær is a vital modern community with such public services as garbage collection from all households, electricity and piped desalinated water. The majority of the residents, 90 people, have their homes on Sørværøy. This is also where the school is located; it is attended by 17 pupils (2006) from grade one through grade six and there is also a kindergarten. On this island, a general store including a mail service is located on the catamaran pier. A community and fisher-owned fish plant is also at the pier, the main harbor of Helligvær. On Sørværøy, there is a café open every Saturday, where residents gather for a cup or three of coffee and sweet homemade cream cakes. The women from the islands bake these cakes on a rotation system.

The community church is placed in the middle of Helligvær, at Storsørøy. Two generations ago, fishing in combination with small-scale farming was the main occupation in Helligvær. Potatoes were grown for local consumption and grass was grown and harvested where it could be found for winter fodder for a few cows and sheep. A pig or two were also kept by some islanders. This adaptation pattern made thorough use of both terrestrial and marine resources. As fishing was the basic income-generating 
activity and exclusively a male occupation, the women had the responsibility for the livestock when their husbands were away for fishing seasonally. Today no cows are grazed on the ancient pastures. This has freed Helligvær women from the daily task of milking and other work in and around the cowsheds. None of the former farmers said that they missed the work with the cows, not even briefly. However, a few families do keep small herds of "Viking sheep" that find sufficient fodder year round on the different islands.

This "new" situation has most of all transformed the duties of many Helligvær wives. Some say they enjoy being at home, caring for their husbands and children. Some explained that the best moments are when the husband is away fishing. Then there is true peace and they can quietly relax around the house. Other women commute to Bodø where they have found satisfying work opportunities. This picture would not be current if we did not pay attention to the young women who find it difficult to find jobs at Helligvær and are not interested in commuting when they still have children younger than four to six years old. These women complain about a lack of job opportunities on the islands.

\section{Flexibility - the yearly cycle of helligvær fishermen}

Helligvær's fishermen have always primarily been occupied by the cod fisheries. The exception to this pattern was a relatively short period beginning in the $1870 \mathrm{~s}$. For some 15 years a frontier-like (Brox 1984; Tsing 2005) herring boom left its mark on Helligvær. Vessels from near and far locations arrived and the community teemed with life during the hectic seasons. There were boats moored at all possible sites. A pub was established where visitors could stay and where an even greater number of fishermen could drink brandy. Police officers from Bodø had to be called in to keep some level of civil order (Gudbrandson 1978). After this 'Klondike', Helligvær returned to normal and to the arctic cod spawning in Vestfjorden that generally has been the trustworthy backbone of their fishing economy. In addition, the Helligvær community is favored by home waters relatively rich in a variety of species that are in demand at international markets.

Modern fishing is highly regulated by catch quotas and strict regulation of the seasons. Thus it is not necessarily the availability of different fish species that limits catches. The first schools of arctic cod on their spawning migration from the Barents Sea reach the waters outside of Troms in January. Approximately a month later they arrive in Vestfjorden where the traditional Lofoten fishery takes place ${ }^{\mathrm{a}}$. For Helligvær fishermen, as with all others, the catch is limited by quotas that vary from vessel to

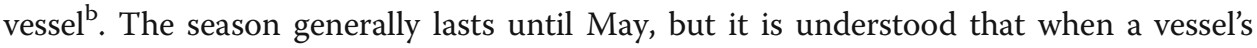
quota is met, fishing must stop; violations are severely fined. Most Helligvær vessels depart for Røst and the winter cod fishing in mid to late February. The crossing takes from six to eight hours over open seas. Most of the fishermen stay at Røst during the entire period and sleep in their vessels. Two types of gear are employed. Vessels with gillnets are usually manned by two men, the owner and a companion ${ }^{c}$. Vessels that are equipped with jigging machines are manned single-handedly. The Røst waters are renowned for stormy weather and harsh working conditions; this implies many idle days at the harbor. Therefore, it is not just a matter of going out and fetching the fish. Usually, some of the vessels do not manage to fill their quotas during the period that the 
arctic cod is around. Those that are successful celebrate by flying the Norwegian flag near the top of the stern mast for all to see on the homerun. Indeed, when the quota of cod is acquired, an important part of the year's income has been secured. Returning from Røst in the spring, the married fishermen are met by their well-dressed wives at the pier in Helligvær. Back home, it is time to rest for a period before those who did not finish the cod quota set out for summer cod fishing off the Finnmark coast. This is a four day journey to reach the fishing grounds from Helligvær.

The remainder of May, June and July is generally a slack period when most of the fishermen are engaged with maintenance work on their vessels and with the upkeep of their homes. Now and then some go out jigging for saithe or redfish. During the summer months, some boys in the14 to 17 age range spend many nights hand-jigging for cod and seithe from a borrowed 11 meter vessel or their own 7 meter vessels. They aspire to the fisherman's life when they get a little older. During the summer vacation from school, they fish on special youth quotas that allow them to sell their catches.

From the end of July through December, the fishermen alternate between different forms of fishing. Some fish for monkfish with gillnets (Broch 2013), while others may set nets for mixed catches of saithe, haddock, pollack (Pollachius pollachius), ling and redfish. A few may go out to jig for whatever may bite on the lures. Some vessels are equipped with halibut lines. Two brothers fish tusk (Brosme brosme) with ocean pots from separate vessels. From August onwards, one of the younger fishermen places his crab (Cancer pagurus) pots nearby and along the Helligvær shores. In late September and early November, two other brothers have for many years set out for Træna, a full day's journey south of Helligvær. Here they stay for two to three weeks jigging saithe from their vessels.

During the first week of August 2010, two vessels left from Helligvær to participate in a short and hectic sprint for the Greenland halibut, fished along the continental slope off Fugløybanken/Tromsøflaket. No one from Helligvær had previously entered their vessel in this fishery. The two vessels caught their quotas in a short time and the expedition was regarded a success. Because the quotas are low, this fishery is well suited for vessels 15 to 20 meters long. In June 2011, the same two vessels headed north for another go at the Greenland halibut in the same area. The fishermen made this decision because there are few good fishing alternatives in June ${ }^{\mathrm{d}}$. One crew did well in spite of difficult conditions due to exceptionally strong deep-sea currents. The other vessel did not get the quota and returned to finish it in the early fall.

Finally, one fisherman experimented with pots for Norwegian lobsters off the Helligvær islands in the spring of 2011. No one from his local community had tried this before. The best period for this enterprise is supposedly during the fall, when he planned to continue the experiment.

Social resilience reflects a communities' current and future adaptive potential to an environment and, most importantly, the ability to cope with uncertainty and unforeseen changes in the same environment. In this context, both aggregated and individual coping strategies become relevant. Adaptive flexibility is highlighted as a necessary precondition for a resilient adaptation that is ultimately connected to the sustainable use of resources.

Resilience theory parallels what human ecologists claimed long ago; generalized niches $^{\mathrm{e}}$ have a more robust or better survival potential than specialized niches 
(Hardesty 1977). A community solely dependent on a single species like cod or other such specialized niche is vulnerable. If the cod for some reason disappeared, the community would have to undergo a complete readjustment, or it could face disintegration. A community that is based on a generalized niche is better able to adjust to ecological changes, as it will have several different opportunities upon which to draw (Kalland and Sejersen 2005). Further Berkes, Colding \& Folke argue that many efforts to control nature by reducing natural resource variation in an effort to make an ecosystem more productive, predictable, economically efficient and controllable may actually lead to a loss of resilience (2003:8). Obviously, resilience is reduced by resource overexploitation and unpredicted consequences of ecosystem collapse or alteration due to various forms of pollution. It is also necessary to comprehend that resilient adaptation, like sustainability, has to be viewed from the long-term perspective of generations, not what might be tomorrow or even in ten to fifty years from now.

A problem with some resilience theoretical approaches is related to notions of optimal development ${ }^{\mathrm{f}}$. One may wonder for whom optimal development or living conditions are designed, anticipated or evaluated. For what type of imagined future society is an adaptation optimal, and based on which values? Likewise when it is argued that social resilience at times may hamper transformation from a current system into a more desirable one (Folke 2006) we run into the same problem. Who should define what is desired and on what social level (local, district or national) attention should be fixed? Issues of power relations and rhetoric are seldom addressed adequately ${ }^{\mathrm{g}}$ in such assessments. In the context of this presentation, focus is on the Helligvær community's resilience, and is not about political goals for national development or global development utopias as are sometimes advocated by powerful politicians and institutions.

The Helligvær ethnography allows for an examination of community resilience. The islands have been settled at least since the Viking Age and appear today to be a remarkably viable fishing community. This may seem surprising when human ecology and resilience theory are addressed. Both models seem to predict reduced resilience and/or adaptive flexibility or robustness when a niche specialization sets in. First we saw that the islanders seemingly reduced their ecological niche, or specialized when they quit farming. This was part of social changes taking place all along the Norwegian coast, as part of modernization; a shift from an economy leaning partly on a domestic mode of production to a more market based economy (Brox 1984; Vea 2009; Jentoft 2011). One effect was that more time could be spent by the fishermen at sea than was possible previously ${ }^{\mathrm{h}}$.

Here I argue that this specialization did not lead to a narrowing of the community's resource base, but rather reorganization. If marine resources (all different species of fish etc.) are regarded as one resource and not as a cluster of different resources, then the niche indeed became more specialized. However, this is not the case as development within the fisheries in the eastern North Atlantic waters clearly show. Crustaceans that were never thought of as food or as having any commercial value are now the target of widespread commercial interests. Some of them, such as the king crab, crab (Canser pagurus) and Norwegian lobsters are all new species in the North. The two latter species have recently been fished from Helligvær. Further, fish species of commercial value and their numbers have always fluctuated. Fishermen adjust to shifting conditions; some species disappear, new species arrive, some abound for a while before their numbers drop drastically. Fishermen live in and base their livelihood 
on a world in flux, and some uncertainty. The survival of the fishery and community viability have always been, and still remain, a consequence of an adequate level of flexibility, professional curiosity and creativity.

During the above mentioned herring boom at Helligvær the local residents adjusted to the situation in several ways; the fishermen engaged in the new fisheries, seasonal paid work for women became abundant and traders and others of both genders found new work options. The boom was short and few were surprised when it ended - or so the narratives go today. The fishermen speculate that the herring may one day return and if so, they will bring forth new gillnets and seines with which to participate in the fishing.

A generation ago, monkfish was thrown overboard when they were entangled in the nets. No one foresaw that monkfish fishing would become a reliable income generating activity in the 2000s. A few years ago, no one predicted commercial fishing for European hake around Helligvær, but recently one fisherman did it successfully during some seasons. Further, large catches of mackerel were brought ashore from Vestfjorden the spring and summer (2011). Mackerel is also a recent new species in the area.

Thus what could at first appear as a specialization of the islanders' niche has actually facilitated a process of niche generalization. The harvest of marine resources has widened to more than compensate for the end of small scale agriculture and the keeping of two or three cows. A larger variety of fish species that have always been present are sought and sold as are crabs and other new species in the area ${ }^{\mathrm{i}}$. Currently Helligvær fishermen claim that a possible shortage of one or two marine species would not threaten their sustainable harvest or the resilient community structure: "If one species disappears there will always be others to fish". The most serious obstacles to community resilience in the present context appear to be political or related to fishing regulations, fishing techniques, and the size and types of vessels favored by the central fishing authorities. Examples of these obstacles are for instance when quotas for cod become too expensive for young local fisher skippers to buy; if automated long liners and Danish seiners frequent Helligvær's home waters more often than now; or if stricter regulations are implemented on, for example, the red fish and monkfish fishery. Another threat feared by coastal fishermen is the politically sanctioned tourist fishing industry. It has been suggested that tourists should be held to the quotas that until now have applied to 11 to 15 meter vessels, particularly for cod. The question of tourist quotas is a consequence of the discovery of the excessive illegal production of fish filets that foreign tourists take home from Norway (Gunnarsdottir 2011). People in Helligvær agree with Jentoft when he observes that fishers often are the primary victims of political mismanagement because the interests of local communities are largely ignored (Jentoft 2005). In spite of such worries by fishermen, Helligvær appears as a robust fishing community allowing continuity in a changing world where many neighboring communities are abandoned or have quit fishing for their livelihood. This cannot be explained by purely ecological causes since fishing conditions are similar all along the North Norwegian coast.

To assess social resilience we need to look into cultural values that motivate, in the present case, small scale coastal fishing. Below we look into how explicit and implicit, idiomatic and idiosyncratic values influence community adaptability or resilience. 


\section{How does life quality relate to the persistence of fishing?}

Based on observations at the global level (Pollnac \& Poggie 2008; Fields 2011) and in Norway (Broch 2006; Maurstad 2010), fisheries are a risky occupation. When this is also common knowledge among the residents of fishing communities, one might wonder why fishing holds such a firm grip on so many men. Why are male youths entering such a risky livelihood and a literally back-breaking career? In Helligvær, many fishermen in their forties and fifties are bothered by work-related physical pains, particularly in the back, elbows and hands. Commercial fishing not only threatens physical wellbeing but entails other risks as well. The economic returns from fishing vary greatly from day to day, between seasons and from vessel to vessel. One would expect the uncertainty about the outcome from the next fishing trip, weather conditions and comparisons between one's own and others' success, to generate significant mental stress.

My ethnographic material suggests no clear-cut answers to this supposition. Individual fishermen experience different levels of success. There are those who are ambivalent about their participation, who alternate between feelings of expressed optimism and pessimism. What individual fishermen say about their profession, skills and work satisfaction differs also according to the contexts of interaction. My participation in the work on different vessels provided a fine way to learn who enjoyed fishing life and who did not. At times, the discrepancy of motives underlying commercial fishing also adds multi-faceted frustrations, as both the fishermen's reputations and identity are negotiated. Every fisherman from Helligvær is expected to enjoy his occupation, and thrive even when fishing is slack. He is supposed to be optimistic and hold that tomorrow may be better. His fishing skills and personality are judged by all community members following these high standards.

In 2007 the winter cod fishery was hampered by the usual strong winds blowing in over Røst. Most of the vessels shorter than 17 meters were stuck in harbor due to the weather. In the evening, fishermen gathered in a café to pass away the time, drink coffee and eat cake. Two brothers who had braved the wind and waves when they set out early that morning, each alone in his 11 meter vessel, were also present. Suddenly, one fisherman from their home community burst out: "Just admit it (as it is), you braved the weather because you are really in need of that money". One of the brothers shook his head, "Peter you've got it all wrong. I enjoy fishing and I never take risks. Right, the weather prediction was bad, but often the meteorologists are wrong. You know as well as I that we can fish in rough conditions and strong winds. It all depends on the exact wind direction and the action of the waves. I just want to have a look myself, to see what the conditions are like. It often makes a difference where you go; the location in which you fish. This morning it was not that bad and my brother and I did well". The one who had asked the question was not satisfied and retorted in an angry voice: "You are taking risks, you need money. That is how it is". It was explained to him that some are used to rougher conditions than most, and therefore sometimes consider the weather to be good enough when others still hesitate to leave the harbor. By now the atmosphere was cooling; there were no more smiles or laughter and several of the fishermen tried to change the topic of conversation.

The above example illustrates that fishermen are not a homogeneous group of successful and contented men. Most of Helligvær's fishermen are however, quite successful 
professionals and it is to both their implicit and expressed motives for persisting in fishing that we now turn.

When I arrived in Helligvær in September 2006, the fishermen reported that here they favored 11 to 15 meter long vessels because they are easily controlled by one person. Yet the deck space allows adequate working conditions for two to three men on the smallest, and up to as many as five people on the 15 meter vessels. However, the fishermen did agree that they preferred to 'row' alone. This was so because most of their equipment could easily be managed single-handedly. Furthermore, it was argued that the catch would only be marginally increased and often not at all when a second fisherman was brought onboard ${ }^{\mathrm{k}}$. The most important reason that was expressed in favor of the small one-man vessels was freedom. Their own fishing adaptation was compared with the life onboard the much larger trawlers, long liners and seiners. They all had some experience from such larger vessels where they said that the work was too routine and monotonous. Skippering one's own vessel affords self-determination as to when and where to row; fishing decisions are all up to the individual fisherman.

The vessel was heading towards the shore after a fine day's catch. The tax lists showing the year's income had just been laid out on the internet for all to see. I asked the skipper (we were alone onboard) how he figured I could argue the efficiency of these small vessels and also present coastal fishing as an attractive occupation when his income was so low? The skipper laughed heartily and said that he trusted my creativity and then he added: "Life quality, Harald. Write about life quality".

Explicit arguments underlining the good life quality of their lived life as commercial fishers are often uttered: "This is the good life, not too warm, a fine breeze and an adequate catch of monkfish". "This is where I am at home, on my own vessel. I cannot imagine a better life". "Yes, it was quite rough today, but I don't mind. It is fine to feel how the vessel runs in the waves. Good to feel one is at sea". "This is almost unbelievable, like being in a fairytale. No wind, sun, sun and sun! So much cod - would not think it possible". "No day is like any other. Always the excitement, the hopes and uncertainty about what the day will bring" (randomly picked statements among many similar field note entries).

All these statements reflect a particular way of their being at home in the world, of being well-adjusted to their social environment and of living in and with the natural environment. I shall argue in keeping with the fishermen, that this feeling of being home is closely connected to a feeling of safety. The vessel is safe, all vessels are not safe, but this vessel has a good reputation, here we are safe (see also Broch 2006). When life quality and fishing are in focus, the aforementioned risks leap once again to the forefront. Several anthropological studies have dealt with the issue and suggest that risks are generally suppressed by most fishermen, as part of their maritime adaptation (Poggie 1980; McGoodwin 1990; Binkley 1995; Broch 2006). When Helligvær fishermen refer to life quality, the risks are a theme that remains unmentioned. However, the twin words 'trust' and 'safety' are both implicitly and explicitly woven into a coherent argument about the fine life experienced at sea. These fishermen are certain in the midst of uncertainty. No one always knows the whereabouts of the fish; a successful trip may be followed by multitude of bad ones. Suddenly all the fish seem to have disappeared, the sea is black, the fishermen say. Yet also in these situations they express a solid faith in safety; they say they love the sea, the vessel, the chase and the never-ending possibility 
of making the outstanding catch, they feel secure. This seemingly fragile safety is based on trust. They trust their own skills to maneuver the vessel and its fishing gear. They trust that their love for the sea will bring them out on the ocean often enough to be present when the fish return. They trust their ability to find fish, both with the help of the computer technology in the wheelhouse, with their accumulated experience and with their intuition. When there is fish to find, they find it. "If some fish stocks disappear there will always be something else to fish" one of the youngest fishermen assured me. The oldest generation of fishermen remembered tough periods, not so much that there was no fish, but terribly low prices and even worse, when no one would buy their catches. Yet they survived and fishermen who own their own 11-meter vessels and work hard shall always make it through and experience some success in the end, they told me.

During my first winter cod season the vessels were tossed about by angry waves and the work hampered by frequent gales. For a while many of the fishermen asked whether I suffered from seasickness and if I managed to stay on my feet or if I was afraid. One fisherman in particular kept asking me when the seas were rough: "Wouldn't you say you're afraid, huh? Just a little?" When he did not get the answer he obviously wished for he ended the enquiry by saying "Admit at least that this is cool (tøfft) and takes some courage". Life quality differs from life style; all the fishermen in Helligvær follow mostly the same routines when they fish. Thus life style connotes a generalized description of how work and leisure activities are interrelated and structured. In contrast, life quality denotes how individuals or specific persons experience their being in the world. This is also different from living standard which surely influences experienced life quality, but favors the successful who earn the most.

Life quality is also influenced by social feedback from significant community members. How efforts and outcomes of an occupation or livelihood are evaluated enforce motivation for particular kinds of work. Cultural values are often expressed in implicit ways, not explicitly admitted by protagonists, but are still highly motivating for a particular adaptation. The following demonstrates how cultural ideas serve as motivation for commercial fishing by enhancing many (particularly young) fishermen's self identity, pride and community position.

Let Sophie, one of the school teachers and a fisherman's daughter represent community sentiments. She is a woman in her fifties, not married to a fisherman. Sophie told me that it was not an easy task to teach most of the local schoolboys to read books; they found them all dull, of little relevance to themselves. However, when she picked the novel "The Last Viking" (Den siste viking) by the Norwegian author Johan Boyer (1950), the boys in class listened and became motivated to read. It is a story about fishermen braving rough times at sea and on shore at the turn of the previous century. The story takes place in Vestfjorden during the Lofoten winter cod fisheries and could well have been about the school children's own great grandfathers. "The novel instills pride in all the children, pride in those they are descended from. Pride in the fishing profession" Sophie claimed.

One evening when I was drinking coffee with Sophie and her husband, she told that she could not help but admire the young and older fishermen in her community. They are the ocean cowboys, daredevils. Many times she had been worried when she watched them. There they came, surfing their small vessels through the narrow inlets, to reach 
calmer waters after a long day at sea in stormy weather. Admittedly, she sometimes recognized the value of their skills and was impressed by their youthful courage. During her childhood and youth, Helligvær fishermen never went out when the conditions were as bad as they often are when the men row these days. To wind up our talk, Sophie confirmed that fishermen seldom talk about risk or dangers at sea, at least not with women: "Some years ago one of our vessels came in after a day of fishing during extremely bad conditions. One of the fishermen was asked by his wife how the day had been at sea in such a rough weather. He answered her that it had been tolerable. Then the woman noticed that her husband was soaking wet and asked if anything particular had happened. He looked bored and uninterested when he told her that the whitecaps had been wild. Not until several months had passed was this wife told that during the storm her husband had fallen into the sea from the vessel!

"Being part of a society that positively values the bravery of fishermen probably has some impact on fishermen's subjective perceptions of risk" (Pollnac and Poggie 2008:195) and confirms their pride. This may be true, but perhaps more important in the present context, where fishermen are indeed respected, even admired for their bravery and success, is how this respect influences gendered speech acts and male fishermen's self evaluations. Both of these topics are colored by the shared idea that fishing represents a positive life quality for manly men.

Sophie came close to describing the fishermen she admires in terms of what has been framed as frontier masculinity (Emel 1998; Anahita \& Mix 2006). Her reference to marine cowboys with their rugged self-sufficiency and great courage is connected to the natural environment where they work. Frontier masculinity has been constructed within the context of wilderness. Sea and ocean environments can easily be defined as typical wilderness areas where men can be truly masculine men, defined by the required physical strength needed to successfully carry out their heavy work, which at times is dangerous. This fishing has been and is regarded by the islanders as a necessary occupation to sustain both household and community viability ${ }^{\mathrm{m}}$.

The argument is that traditional gender roles operate well in contemporary Helligvær. Here the situation is remarkably different from the reported crisis in masculinity among Newfoundland fishermen. According to Davis (1993), the crisis in the fisheries there led to a perceived feminization of men when they could no longer be men in culturally prescribed ways. Power argues that Davis makes an analytic error, because the men in focus find new ways of doing gender. Canadian men who were earlier engaged within the fisheries seem to adapt to the new situation and change their ideas about who are men and what they may do (Power 2005:106). Also at Helligvær, there are more accepted or recognized ways of doing male gender than solely by a lifestyle based on fishing. For example, the trader at the local shop, a male teacher at the local school, an electrician and an airplane technician all working in Bodø are all respected men. The point is that successful fishermen are admired as the manliest of men, and serve as ideal role models for many local boys. The fishermen are the "last Vikings"; they live competitive lives and good catches are there to be seen and celebrated at the pier. No fisherman in Helligvær would admit that approval or praise of their masculinity is a motivating factor, adding to their conceived life quality. The empirical evidence, however suggests otherwise. 
Fishing is an occupational arena where some youths achieve triumph, alongside their older counterparts. They are met with generous positive feedback from fellow community members of both genders and explicitly ascribed a socio-cultural and economic force that lays the foundation for the viability of both the contemporary and future Helligvær community. I never heard fishermen suggest that they fish because they want to be considered or to feel like real men. Yet, they often express attitudes that firmly place fishing as indeed men's work. Interestingly, it was particularly the younger fishermen (and two that were pensioned) who most rigidly insisted that women were not fit for the strenuous life onboard their small vessels. The well-established fishermen were more open-minded, perhaps there could be a few women who would thrive at sea, they admitted. This difference in expressed attitudes may well suggest that the male identity project was most important for the youngest fishermen.

The islanders seem to agree that if the commercial fishing based in Helligvær were to cease, the community would decline and relatively soon become depopulated. This is a pattern they have seen more than once when neighboring communities disappeared. My field experiences onboard the vessels and many conversations in Helligvær strongly suggest that male pride, manhood making and ascribed male identity, by self and others, supply much motivational force to becoming a fisherman. An imagined or real situation where self-ascribed identity equates to the identity ascribed by significant others should nurture some psychological stability or contentment and, in the present context, work satisfaction.

\section{The future and the question of social resilience}

At the beginning of this article it was argued that the concept of community resilience and the emic notion of life quality are closely linked. Resilience focuses on how, in the Helligvær context, fishing is carried out. Which resources are harvested and what are the consequences for predicted or assumed sustainability? The analytical power of resilience lies in the notion of the importance of absorbing or dealing adequately with unforeseen or surprising changes or developments in an environment. Resource utilization reflects lifestyles and adaptation patterns that connect human and environmental systems firmly together. The capacity of human actors to influence resilience is an outcome of cultural factors including community values and feedback. Life quality was coined as resulting from how one experienced and made sense of one's own life style. Life quality was understood as an outcome of how individuals, contexts and shared values interact (Vitters $\varnothing$ 1991). Positive life quality is suggested as an outcome of an experience triggering both individual pride, as with fishing as a cherished goal in itself and a source of economic satisfaction. Thus many stranded positive community feedback is essential to community resilience through an experienced positive life quality.

It is a general assumption that there are too many fishers chasing too few fish (McGoodwin 1990; Power 2005; Roberts 2007; Pollnac and Poggie 2008). To the extent this is a globally correct assessment, that conclusion may lead to different options regarding how fish should be caught and by whom. This is another question about what type of future societies one strives to support and develop. A substantial reduction of the number of fishing vessels may still fish more than currently as when seiners and trawlers put small vessels out of business and take over. Seiners and trawlers cause far 
more submarine environmental damage than 11 to 15 meter long vessels. As indicated above, Helligvær vessels fish well enough to secure a financially adequately living standard. Their catches are often limited by the size of the crafts, not the availability of fish such as cod or Greenland halibut.

Given a well-functioning system of catch quotas, adjusted to the robustness of targeted fish stocks, this type of coastal fishing adaptation is probably more ecologically sustainable than most other types of fishing. The largest threats to reduced local community resilience, according to the fishermen, seem to be planned drilling for oil and continued seismic explorations in Vestfjorden, the Lofoten area and Helligvær's home waters. Trawling for calanus also worries these fishermen. They believe that industrial plankton fishing may cause a negative food situation for many different marine species in the area. The implementation of national development plans to secure and expand the production of fossil non-renewable and so-called green wind energy will surely affect the resilience of some fishing communities. The best and most interesting areas for oil and gas exploration, windmills or fishing alike are the same relatively shallow banks off the coast that support good fishing.

Changes in ocean temperatures could affect fishing in more ways around Helligvær than hitherto experienced. In the case of Norwegian west coast fishermen it is argued that climatic changes will most likely not represent a big challenge. Their attitudes to fishing have always been dynamic and they are used to changing the way they fish in order to deal with existing conditions (Strømgren 2006:179). We saw that the same goes for Helligvær. It was also argued above that when the continuity of local community resilience is assessed, political regulations and agendas may represent a greater risk than depletion of potential and utilized resources. As 95\% of Norwegian fish are exported, international trade agreement or rules will have a direct influence on local communities along the entire Norwegian coast (Strømgren 2006: 179).

Community resilience is not only dependent on how, for instance, fishing is technically carried out: if so Helligvær would not be only one of few viable, vigorous local fishing communities in the Norwegian north. In contrast to many other communities that also are rich in marine resources in Northern Norway, recruitment of young fishermen to the local fleet has not been a problem ${ }^{\mathrm{n}}$. Because fishing as a life style is generally similar, we have to search for possible causes elsewhere. Life quality appears to be one important explanatory factor among others.

Interestingly, current recruitment to fishing in Helligvær appears to follow some characteristics of the coastal employment system for the Norwegian coasts of the 1980s. This system depended on informal, affective social relations and a high degree of social commitment. Recruitment and employment depended on social relations and locally transferred knowledge (Jentoft \& Wadel 1984). The germ of a modern and specialized fishery employment system was however, detected when two Helligvær boys received relevant fishery training through the formal schooling system. Yet this new type of fishery recruitment and training described by Sønvisen et al. (2011:48) had not affected Helligvær to any significant degree by 2010.

"Life quality", the young Helligvær fishermen say, "that is why we fish - that is why we love this life". The expressions of fishing as representing a life way that reflects a sought-after life quality are thoroughly embedded in cultural idioms and agreed upon Helligvær values. Many of these values are well known from several cross-cultural 
studies of fishing communities, from different parts of the world. Freedom of choice, self-sufficiency, the possibility of the unprecedented large catch, the thrill of excitement and perpetual new possibilities are among the commonly emphasized characteristics of these adaptation practices. All these values are linked to life quality also because they resonate with inhabitants of Helligvær and are shared community ideals. Given that these are culturally constituted arguments, they could also be clichés, or part of a conventional way of self presentation. Even if this was so, if one believes that these arguments are held by one's fellow fishermen, this speech practice may well influence the way most (but not all as we have seen) fishermen think about fishing. For most people there is some comfort and safety in reasonable conformity. This is especially so when conventional expressions provide social appreciation from significant others. To go against such common appraisals of a fisherman's self presentation would at best be regarded as self-degrading, or worse, as the tale of a misplaced person who has no future within the local fisheries: the few who fish because they see no alternative.

It is thus argued that traditional cultural values ascribe high social value and position to fishing within the social community hierarchy in Helligvær. The fishermen are certainly aware of this recognition and it adds to their experienced life quality. The notion of 'life quality' is conceptualized as comprising many separate values that serve as a composite of motivations to undertake Helligvær fishing activities. My understanding, based on observations and conversations in Nordland and Troms, is that the setting at Helligvær differs from many other communities. For centuries, the Helligvær community has been conceptualized by the residents as a fishing community. Here maleness is associated with and attached to commercial fishing, an occupation where men prove their manhood at sea. Helligvær has an integral fishing milieu where fishermen are highly respected and a local school that installs pride in youngsters who wish to maintain the local fishing tradition.

The combination of local know-how about marine resources, changing environmental conditions perceived as possibilities, and cultural values fostering male pride in successful fishermen have been ingredients leading to centuries of what can be labeled as community resilience.

Recently wellbeing, work satisfaction, and happiness have been suggested as constitutive elements of community resilience (McCay 2012). Individual indications of happiness (and pride, I would add) are experienced, savored, and expressed in intimate and often transmittable ways, as a form of sensory currency that both sustains and motivates (Johnston 2012) particular patterns of adaptation. Successful fishermen were the focus of this article because they clearly were the majority of the fishermen with whom I worked. It is their self-presentation and impression management (Goffman 1959) that informed the account and analysis of Helligvær as an example of lived community resilience. If the social resilience of communities is to be calculated not only presumed life style and living standard should be taken into account. The analysis presented above also shows that we need to consider the life quality of significant actors.

\section{Endnotes}

${ }^{a}$ The winter cod fisheries of 2011 were the best in many years and arctic cod penetrated deep into the fjord after many years of absence. During the ten or so foregoing 
years the cod migration stopped around Røst, the outmost of the Lofoten chain of islands.

${ }^{b}$ Generally all vessels fish on a basic quota adjusted to the size of the vessel. In addition it is possible, according to some special rules, to transfer a quota from an older vessel to a new one. Further quotas can be bought on the open market.

${ }^{\mathrm{c}}$ One father-and-son crew was also fishing during two of the three seasons I attended the winter cod fisheries.

${ }^{\mathrm{d}}$ The Greenland halibut season is divided between two periods, one in late spring and the other in early fall. The quota for each vessel participating is fixed. Vessels that do not manage to fish the quota during the first period may fish the rest during the second period. Otherwise it is voluntary to decide between the first, second or to combine both periods for fishing.

${ }^{\mathrm{e}} \mathrm{Nich}$ is defined as the sum of resources utilized, a generalized niche contains many resources, whereas the specialized niche is narrow, based on one or a few resources only.

${ }^{\mathrm{f}}$ See for instance Folke 2006.

${ }^{\mathrm{g}}$ Hastrup (2009) and Nuttall (2009) are exploring the usefulness of the concept of resilience in anthropological analysis and also are addressing these questions.

${ }^{\mathrm{h}}$ This argument is simplified as several other factors contribute(d) to adaptation strategies. Such factors include technological development both in the fisheries and in other spheres of importance to social well-being. Market prices on fish and market availability, community services and shared cultural values, geographical locality and more, all have an aggregated impact on community resilience.

${ }^{\mathrm{i}}$ Because focus here is on Helligvær as a fishing community, I am not measuring the significance of new job opportunities in the 'vær' and on the mainland. These possibilities are generally a consequence of improved transport facilities to and from the islands.

${ }^{\mathrm{j}}$ To row (ro in Norwegian) is the conventional expression used for fishing.

${ }^{k}$ When more vessels went gillnet fishing in the following years, especially during the winter cod and Greenland halibut fisheries, crews of two and three men became common $(2008$ - 2011).

${ }^{1}$ This and similar statements are conventional, honest, but also contextually formulated. Although true in the sense that the ideas have motivational force, there are nevertheless other contexts that are seldom mentioned and generally suppressed. Bank loans must be handled and there are even wives who some days urge their men to go and row.

minterestingly, this frontier masculinity seems close to the personality type Pollnac and Poggie (2008) suggest has selective force for success among fishermen.

${ }^{\mathrm{n}}$ See Jentoft 2011 for a brief explanation for the recruitment crisis in Norwegian fisheries. 


\section{Acknowledgements}

This research is part of the project "Cultures of Biodiversity: Perceptions and Practices" based at the Department of Social Anthropology, University of Oslo, and supported by the Norwegian Research Council, Project No 204326. I would like to thank two anonymous reviewers and the Maritime Studies editor for many useful comments to the first version of this article.

Received: 29 April 2013 Accepted: 29 April 2013

Published: 30 August 2013

\section{References}

Anahita, S, and TL Mix. 2006. Retrofitting Frontier Masculinity for Alaska's War against Wolves. Gender and Society 20(3): 332-353.

Berkes, F, J Colding, and C Folke. 2003. Introduction. In Navigating Social-Ecological Systems. Building Resilience for Complexity and Change, ed. F Berkes, J Colding, and C Folke, 1-29. Cambridge: Cambridge University Press.

Binkley, M. 1995. Risks, Dangers and Rewards in the Nova Scotia Offshore Fishing. Montreal, Mac Guill: Queens University Press.

Boyer, J. 1950. Den siste Viking (the last Viking). Gyldendal: Oslo.

Broch, HB. 2006. Strategies of Coping with Fright and Risk onboard Norwegian Fishing/Whaling Vessels. Suomen Anthropology 31(2): 2-18

Broch, HB. 2013. Monkfish Mysteries. A Narrative Analysis of Place- making and Knowledge Production among North Norwegian Fishermen. Acta Borealia: A Nordic Journal of Circumpolar Societies. doi:10.10.80/08003831.2013.768055.

Brox, O. 1984. Nord-Norge fra allmenning til koloni, North Norway from Commons to Colony. Tromsø: Universitetsforlaget.

Clay, PM, and J Olson. 2007. Defining Fishing Communities: Issues in Theory and Practice. Napa Bulletin 28: 17-42.

Davis, DL. 1993. When Men become Women: Gendered Antagonism and the Changing Sexual Geography of Work in Newfoundland. Sex Roles 29(7/8): 457-475.

Emel, J. 1998. Are you Man Enough, Big and Bad Enough? Wolf Eradication in the US. In Animal Geographies. Place, Politics and Identity in the Nature-Culture Borderland, ed. J Wolch and J Emel, 91-116. London: Verso.

Fields, LL. 2011. Hooked! Kenmore: Epicenter Press.

Folke, C. 2006. Resilience: The emergence of a perspective for social-ecological system analysis. Global Environmental Change 16: 253-267.

Goffman, E. 1959. The Presentation of Self in Everyday Life. Garden City, N.Y: Doubleday Anchor.

Gudbrandson, T. 1978. Bodin Bygdebok IIII (The local communities of Bodin II-I). Bodø Municipality (Counsel): Bodø.

Gunnarsdottir, M-V. 2011. Northern Norway Responding to Change: Shifting from Traditional Small-Scale Fishing to Marine Fish Tourism. Paper presented in Amsterdam, Netherlands at the Mare Conference: People and the Sea VI. Hardesty, D. 1977. Ecological Anthropology. New York: John Wiley \& Sons.

Hastrup, K. 2009a. Waterworlds: Framing the Question of Social Resilience. In The Question of Resilience. Social Responses to Climate Change, ed. K Hastrup, 11-30. København: Det Kongelige Danske Videnskabernes Selskab.

Hastrup, K. 2009b. Arctic Hunters: Climate Variability and Social Flexibility. In The Question of Resilience. Social Responses to Climate Change, ed. K Hastrup, 245-270. København: Det Kongelige Danske Videnskabernes Selskab.

Hollan, D. 2001. Developments in person-centered ethnography. In The Psychology of Cultural Experience, ed. C Moore and HF Mathews, 48-67. Cambridge: Cambridge University Press.

Hollan, D. 2012. On the Varieties and Particularities of Cultural Experience. Ethos 40(1): 37-53.

Jentoft, S. 2005. Introduction Part 3. In Fish for Life. Interactive Governance for Fisheries, ed. J Kooiman, M Bavinck, S Jentoft, and R Pullin, 147-151. Amsterdam: Amsterdam University Press.

Jentoft, S. 2011. Fisheries development as freedom. In World Small-Scale Fisheries, Contemporary Visions, ed. R Chuenpagdee, 367-379. Eburon: Delft.

Jentoft, S, and C Wadel. 1984. Sysselsettingssystem som analytisk begrep (Coastal employment system as ananytic consept). In I samme båt - Sysselsettningssytem i fiskerinæringa, ed. S Jentoft and C Wadel, 180-187. Oslo: Universitetsforlaget.

Johnston, BR. 2012. On Happiness and transformative change. American Anthropologist 114(1): 15-18.

Kalland, A, and F Sejersen. 2005. Marine Mammals and Northern Cultures. Edmonton: Canadian Circumpolar Institute (CCI) Press. McCay, B. 2012. Happy as a clam: A comedy. American Anthropologist 114(1): 11-12.

Maurstad, A. 2010. Cultural seascapes as embodied knowledge. In Mutuality and Empathy. Self and other in the ethnographic encounter, ed. AS Grønseth and DL Davis, 35-48. London: Sean Kingston Publishing.

McGoodwin, JR. 1990. Crisis in the World's Fisheries: People, Problems and Politics. Stanford: Stanford University Press.

Nuttall, M. 2009. Living in a World of Movement: Human resilience to Environmental Instability in Greenland. In Anthropology \& Climate Change. From Encounters to Actions, ed. SA Crate and M Nuttall, 292-310. Walnut Creek, CA: Left Coast Press.

Olwig, MF. 2009. Climate Change $=$ Discourse Change? Development and Relief Organizations' Use of the Concept of Resilience. In The Question of Resilience. Social Responses to Climate Change, ed. K Hastrup, 314-335. København: Det Kongelige Danske Videnskabernes Selskab.

Poggie, JJ. 1980. Ritual adaptation to risk and technological development in ocean fisheries: Extrapolations from New England. Anthropological Quarterly 53(2): 122-129.

Pollnac, RB. 1988. Social and Cultural Characteristics of Fishing Peoples. Marine Behaviour and Physiology 14: 23-39.

Pollnac, RB, and JJ Poggie. 2008. Happiness, Well-being and Psychocultural Adaptation to the Stresses Associated with Marine Fishing. Human Ecology Review 15(2): 194-200.

Power, NG. 2005. The "Modern Fisherman". Masculinity in Crisis or resilient Masculinity? Canadian Woman Studies 24: 102-197. Nr. 4

Roberts, C. 2007. The Unnatural History of the Sea. The Past and Future of Humanity and Fishing. London: Gaia. 
Sherrieb, K, and FH Norris. 2009. Community Resilience and Health outcomes in Mississippi Counties. In The Question of Resilience. Social Responses toClimate Change, ed. K Hastrup, 70-87. København: Det Kongelige Danske Videnskabernes Selskab.

Smith, B, and D Goldblatt. 2000. Whose health is it anyway? In The Natural and the Social: Uncertainty, Risk, ed. S Hinchliffe and K Woodward, 43-77. Change. London: Routledge and The Open University.

Strømgren, T. 2006. Vestnorsk kystkultur - øysamfunnet Batalen. Bind 2A - Fiskeri - Fishery. Batalden, Norway: Stromgren Publishing.

Sønvisen, SA, JP Johnsen, and J Vik. 2011. The Norwegian coastal employment system: what it was and what it is. Mast 10(1): 31-56.

Tsing, AL. 2005. Friction. An Ethnography of Global Connection. Princeton University Press: Princeton.

Tuler, S, I Agyeman, P Pinto da Silva, KR LoRusso, and R Kay. 2008. Assessing Vulnerabilities: Integrating Information about Driving Forces that Affect Risks and Resilience in Fishing Communities. Human Ecology Review 15(2): 171-184.

Vea, J. 2009. To kulturer (Two Cultures). Kristiansand: Høyskoleforlaget (Norwegian Academic Press).

Vittersø, J. 1991. Livskvalitet i et jegersamfunn. Om utviklingsprosesser i Grønland (Life quality in a hunting community. On development processes in Greenland), Thesis submitted for the Master degree in social anthropology. Oslo: University of Oslo.

doi:10.1186/2212-9790-12-6

Cite this article as: Broch: Social resilience - local responses to changes in social and natural environments. Maritime Studies 2013 12:6.

\section{Submit your manuscript to a SpringerOpen ${ }^{\circ}$ journal and benefit from:}

- Convenient online submission

- Rigorous peer review

- Immediate publication on acceptance

- Open access: articles freely available online

- High visibility within the field

- Retaining the copyright to your article

Submit your next manuscript at $\boldsymbol{\sim}$ springeropen.com 